University of Nebraska - Lincoln

DigitalCommons@University of Nebraska - Lincoln

USDA Forest Service / UNL Faculty Publications U.S. Department of Agriculture: Forest Service -National Agroforestry Center

1997

\title{
Identification of Three Randomly Amplified Polymorphic DNA- Polymerase Chain Reaction Markers for Distinguishing Asian and North American Gypsy Moths (Lepidoptera: Lymantriidae)
}

\author{
David E. Schreiber \\ USDA Forest Service \\ Karen J. Garner \\ USDA Forest Service \\ James M. Slavicek \\ USDA Forest Service
}

Follow this and additional works at: https://digitalcommons.unl.edu/usdafsfacpub

Part of the Forest Sciences Commons

Schreiber, David E.; Garner, Karen J.; and Slavicek, James M., "Identification of Three Randomly Amplified Polymorphic DNA-Polymerase Chain Reaction Markers for Distinguishing Asian and North American Gypsy Moths (Lepidoptera: Lymantriidae)" (1997). USDA Forest Service / UNL Faculty Publications. 126. https://digitalcommons.unl.edu/usdafsfacpub/126

This Article is brought to you for free and open access by the U.S. Department of Agriculture: Forest Service -National Agroforestry Center at DigitalCommons@University of Nebraska - Lincoln. It has been accepted for inclusion in USDA Forest Service / UNL Faculty Publications by an authorized administrator of DigitalCommons@University of Nebraska - Lincoln. 


\title{
Identification of Three Randomly Amplified Polymorphic DNA-Polymerase Chain Reaction Markers for Distinguishing Asian and North American Gypsy Moths (Lepidoptera: Lymantriidae)
}

\author{
DAVID E. SCHREIBER, KAREN J. GARNER, AND JAMES M. SLAVICEK ${ }^{1}$ \\ Northeastern Forest Experiment Station, USDA Forest Service, \\ 359 Main Road, Delaware, OH 43015
}

\begin{abstract}
Ann. Entomol. Soc. Am. 90(5): 667-674 (1997)
ABSTRACT Gypsy moths originating in Asia have recently been introduced into North America, making it necessary to develop markers for distinguishing the Asian strain from the established North American population. We have identified 3 randomly amplified polymorphic DNA-polymerase chain reaction generated (RAPD-PCR) markers which are specific for either Asian or North American moths. The FS-2 and FS-3 markers are specific for the North American strain, and the FS-4 marker is specific for moths from far east Asia. The 3 RAPDamplified fragments have been cloned and sequenced, and locus-specific primers have been developed for the FS-3 marker. These markers, in combination with other markers already available, will be useful for increasing the accuracy of identification of suspect moth specimens.
\end{abstract}

KEY WORDS gypsy moth, randomly amplified polymorphic DNA-polymerase chain reaction, sequence-characterized amplified region

GyPsy мотнS, Lymantria dispar (L.) originating in Europe were introduced into Massachusetts in 1869 (Forbush and Fernald 1896). The moths have since spread throughout New England and adjacent areas of Canada, and the leading edge of the infestation has reached Maine, Michigan, Ohio, North Carolina, Virginia, and West Virginia. Isolated gypsy moth outbreaks have been reported in almost every state in the continental United States. Although efforts are being made to control defoliation at outbreak sites and to slow the spread of the infestation, the North American gypsy moth is considered too well-established to eradicate.

In 1991, Asian gypsy moths were discovered on ships attempting to enter ports in the Pacific Northwest (Gibbons 1992, Mudge et al. 1994, Wood 1994). The Asian strain can survive and grow better than the established North American gypsy moth, particularly on hosts such as Douglas fir (Pseudotsuga menziesii) that are of intermediate suitability (Montgomery and Baranchikov 1995). In addition, the Asian females, unlike those of the North American strain, can fly, and thus the Asian moths may be capable of more rapid migration (Wallner et al. 1994, Keena et al. 1995). For these reasons, the decision has been made to attempt to eradicate known Asian gypsy moth infestations in the United States. To date, Asian moth introductions have been detected and eliminated in the Pacific North-

\footnotetext{
${ }^{1}$ To whom reprint requests should be sent.
}

west in 1991, 1993, and 1994 (Mudge et al. 1994, Wood 1994) and in North Carolina in 1993 (South 1994). Monitoring for Asian gypsy moths is continuing in port regions of the United States and Canada.

Gypsy moth populations are monitored using pheromone-baited sticky traps. Although the Asian and North American gypsy moths have significant behavioral differences, they are morphologically similar and trapped specimens in particular may be indistinguishable because of damage to the samples. DNA amplification using the polymerase chain reaction (PCR) offers a method for obtaining genetic information from very small or poorly preserved specimens; therefore, strain-specific DNAbased markers for identifying trapped insects have been sought. A mitochondrial DNA marker is currently in use (Bogdanowicz et al. 1993) but because of maternal inheritance of mitochondria, this marker is unable to detect the paternal genotype in the case of hybrid moths. Asian and North American gypsy moths are frequently capable of hybridization under laboratory conditions (Keena 1994a, b, Keena et al. 1995). When these hybrids are evaluated for traits such as diapause chill requirements, larval color, adult size, and female flight capability, the hybrids are usually intermediate between the Asian and North American forms, or else more closely resemble the Asian parent. Because the characteristics of future generations of hybrid gypsy moths cannot be predicted, it is desirable to 
be able to detect the Asian genotype in mixed populations of moths.

Two nuclear DNA markers for gypsy moth strains have been reported. One uses ribosomal DNA amplification followed by restriction site polymorphism analysis (Pfeifer et al. 1995) and the other consists of a sequence-characterized amplified region (SCAR) DNA-length polymorphism (Garner and Slavicek 1996). However, additional nuclear DNA markers would be useful in conjunction with those already available for more statistically valid identification of specimens.

To identify markers, we used the randomly amplified polymorphic DNA polymerase chain reaction (RAPD-PCR) technique. Briefly, RAPD-PCR involves the use of short oligonucleotides as primers and nonstringent reaction conditions to amplify multiple DNA fragments, which are often polymorphic within populations (Williams et al. 1991). RAPD-PCR has been used to identify markers in a wide variety of plants and animals, including several species of insects (Gawel and Bartlett 1993, Favia et al. 1994, Dowdy and McGaughey 1996, Garner and Slavicek 1996). RAPD-PCR has also been used to assess genetic variability in German gypsy moths, although markers for regional populations have not been defined (Graser et al. 1995).

As a result of testing 300 RAPD primers on Asian and North American gypsy moths of known origin, we have identified 3 RAPD-PCR markers, denoted FS-2, FS-3, and FS-4, which identify Asian and North American gypsy moths with a high degree of accuracy. We have further characterized these markers by cloning and sequence analysis. In addition, it was possible to develop locus-specific primers for the FS-3 marker based on the nucleotide sequence.

\section{Materials and Methods}

DNA Samples. Asian gypsy moth samples used in screening decanucleotide primers were collected in China (Beijing, Hubei, Liaoning, and Shandong), Japan (Hokkaido, Kashiwada, Kukisaki, Namiki, and Sakuragaoka), Russia (Mineralni in Primor'ye Territory and Bellyk in Krasnoyarsk Territory) or were reared from egg masses collected from ships originating in Vladivostok, Russia. North American moths were collected from Massachusetts (Norfolk County), Michigan (Manistee, Newaygo, Oceana, and Ottawa counties), North Carolina (Currituck and Dare counties), Ohio (Ashtabula County), Pennsylvania (Fayette and Somerset counties), and West Virginia (Monongalia County). North American moths were not collected in regions known to be affected by recent Asian introductions. Asian traits such as female flight have not been described in established North American populations; however, the possibility of genetic contributions from past undetected Asian introductions into the North American population cannot be ruled out. Hybrids were generated at the
USDA Forest Service Quarantine Laboratory, Ansonia, CT, from individuals of known geographic origin. Matings were done with females from Asia crossed with males from North America and females from North America crossed with males from Asia.

DNA Preparation. DNA was extracted from individual larvae, pupae, or adult gypsy moths using a method adapted from Ish-Horowicz et al. (1979). Samples weighing up to $0.5 \mathrm{~g}$ were used whole; portions of larger specimens were used. The tissue was homogenized in a glass homogenizer in 2-ml grind buffer $(10 \mathrm{mM}$ Tris-Cl pH 7.5, $60 \mathrm{mM} \mathrm{NaCl}$, $10 \mathrm{mM}$ EDTA). An equal volume of post grind buffer (200 mM Tris-Cl pH 9, $30 \mathrm{mM}$ EDTA, $2 \%$ wt:vol SDS) was added to the homogenate and Proteinase $\mathrm{K}$ was added to a final concentration of $200 \mu \mathrm{g} / \mathrm{ml}$. The mixture was incubated at $55^{\circ} \mathrm{C}$ for 4-16 $\mathrm{h}$, then sodium acetate was added to a final concentration of $0.3 \mathrm{M}$. The solution was extracted with an equal volume of buffered phenol, then with an equal volume of chloroform/isoamyl alcohol (24:1). The DNA was precipitated with 2 volumes of ethanol, pelleted, and resuspended in water. The DNA was then treated with RNAse $(50 \mu \mathrm{g} / \mathrm{ml})$ at $37^{\circ} \mathrm{C}$ for $2 \mathrm{~h}$, and then was reextracted with phenol and chloroform followed by ethanol precipitation and resuspension. DNA prepared from larvae usually required further purification using an Elutip-D column (Schleicher and Schuell, Keene, NH), following manufacturer protocol.

Polymerase Chain Reaction Methods. RAPDPCR was carried out in $25-\mu \mathrm{l}$ reactions containing 10 ng genomic DNA, $50 \mathrm{mM} \mathrm{KCl}, 10 \mathrm{mM}$ Tris-Cl pH 9.0 and $2.0 \mathrm{mM} \mathrm{MgCl} 2,0.2 \mu \mathrm{M}$ primer, and 0.2 units Taq DNA polymerase (Boehringer Mannheim, Indianapolis, IN). Reactions were topped with mineral oil and amplified in a Perkin Elmer (Foster City, CA) thermal cycler for $2 \mathrm{~min}$ at $94^{\circ} \mathrm{C}$ (denaturation step) followed by 45 cycles of $94^{\circ} \mathrm{C}$ for 1 $\min , 36^{\circ} \mathrm{C}$ for $1 \mathrm{~min}$, and $72^{\circ} \mathrm{C}$ for $2 \mathrm{~min}$. PCR with locus-specific primers was carried out in the same manner except that the primer concentration was $0.4 \mu \mathrm{M}$ for each primer, the annealing step of the PCR program was carried out at $50^{\circ} \mathrm{C}$, and the extension step was 1 rather than 2 min long. DNA amplification was analyzed by electrophoresis in $1.2 \%$ agarose gels using Tris-borate buffer followed by ethidium bromide staining of the DNA.

Screening of RAPD PCR Primers. Primer sets OPE through OPS (20 primers in each set) were purchased from Operon (Alameda, CA) and used to amplify 3 DNA samples from each geographic location. Any primer that appeared to amplify a diagnostic fragment was tested with increasing numbers of samples until up to 100 individuals of each strain had been analyzed.

Characterization of RAPD-Generated Fragments. Diagnostic bands were gel purified and then cloned into the pCRII vector from the TA Cloning Kit (Invitrogen, Carlsbad, CA) following manufacturer instructions. Amplified DNA from a represen- 
Table 1. Locus-specific primer sequences selected and tested for utility in amplification of the FS-2, FS-3, and FS-4 markers

\begin{tabular}{|c|c|}
\hline Primer names & Sequences \\
\hline \multicolumn{2}{|l|}{ FS-2 } \\
\hline OPG-03 & $5^{\prime}$ GAGCCCTCCA $3^{\prime}$, \\
\hline G311F & 5'GAGCCCTCCAT 3', \\
\hline G315F & 5' GAGCCСTCСАТTCTT 3', \\
\hline $\mathrm{G} 320 \mathrm{~F}$ & 5'GAGCCCTCCATTCTTCACC 3', \\
\hline G311R & $5^{\prime}$ GAGCCCTCCAC $3^{\prime}$, \\
\hline G315R & 5'GAGCCCTCCACACGA $3^{\prime}$ \\
\hline G320R & 5'GAGCCCTCCACACGAAAATT $3^{\prime}$, \\
\hline G3/4R & 5'CGTCTATAGCCTCTTCATATTAG 3' \\
\hline $\mathrm{G} 3 / 4 \mathrm{~F}$ & 5' GAAATAGGTTCGGCGGTTTAAGCG 3' \\
\hline FS-2 U560 & 5'TTACAAACAGACACTCCAAT $3^{\prime}$ \\
\hline FS-2 L438 & 5'TTTGTTCCGGGTAATCCTCA 3' \\
\hline FS-2 U86 & 5'TATTATAGCTTTCATTGGAT 3' \\
\hline FS-2 U143 & 5' GAAAACGTAAGAAATAAAAC 3' \\
\hline FS-2 L812 & 5'AGGTGCAAGTGTCAAGTCAT 3' \\
\hline \multicolumn{2}{|r|}{ 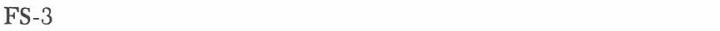 } \\
\hline OPH-11 & 5'CTTCCGCAGT 3' \\
\hline H11 IF & 5'CTTCCGCAGTGTCTGAATAC 3' \\
\hline H11 IIF & $5^{\prime}$ TGCTATAGAGAGgGTTATGCTCGG $3^{\prime}$ \\
\hline H11 IR & 5'CTTCCGCAGTCCATACCACA 3' \\
\hline H11 IIR & 5'GACGCGTCAGTTAGAATCTTCACA 3' \\
\hline \multicolumn{2}{|r|}{ (2) } \\
\hline OPP-03 & $5^{\prime}$ CTGATACGCC $3^{\prime}$ \\
\hline P3 IF & 5'CTGATACGCCATTATTGCAGTTTG 3' \\
\hline P3 IIF & 5'GATATGTAGTTTCCAATTAC 3' \\
\hline P3 IIIF & 5' CCCAAGAATATACAATCGTTAACC 3' \\
\hline P3 IR & $5^{\prime}$ CTGATACGCCGCTGGTGGGTTG $3^{\prime}$ \\
\hline P3 IIR & 5' CCCTTAGTCGTCTTATACGAC 3' \\
\hline P3 IIIR & 5'GAGGGTAATGAATTGTATTC 3' \\
\hline
\end{tabular}

The primers whose names begin with OP were purchased from Operon. The remaining primers were designed based on marker sequences as described in Materials and Methods.

tative RAPD-PCR gel was blotted onto a nylon hybridization membrane. To confirm that the correct DNA fragment was cloned and also that amplified DNA fragments appearing to be the same size were actually homologous, gel-purified plasmid insert DNA was labeled using the Gibco BRL Nick Translation System (Grand Island, NY) and hybridized to the RAPD-PCR blot. Clones of diagnostic fragments were sequenced with the $f \mathrm{M}$ sequencing kit (Promega, Madison, WI) or with the Sequenase sequencing kit (United States Biochemical, Cleveland, $\mathrm{OH}$ ).

Selection of Locus-Specific Primers. The OLIGO Primer Analysis software package (Rychlik 1992) was used to design PCR primer sequences. This program selects primer pairs having suitable guanine and cytosine content and compatible annealing temperatures and disqualifies primer sequences having possible multiple binding sites, internal secondary structure or primer interactions. The locusspecific primer sequences selected and tested are shown in Table 1.

Genomic Southern Blots. Twenty micrograms of genomic DNA were digested with $\mathrm{BamHI}$ and run on a $0.8 \%$ agarose gel. To ensure that the digestion was complete, a $7.5 \%$ portion of the restriction enzyme reaction mix was removed to a separate tube and $0.5 \mu \mathrm{g}$ of lambda phage DNA was added. The lambda DNA was allowed to digest under the same conditions as the remainder of the genomic DNA.
The lambda DNA was checked on a separate gel for completeness of digestion before the remainder of the genomic DNA was used for blotting. After electrophoresis the gel was blotted onto nylon hybridization membrane.

The FS-2, FS-3, and FS-4 plasmid insert DNA fragments were radioactively labeled using the Gibco BRL Nick Translation System. Unincorporated dNTPs were removed using a Sephadex G-50 (Pharmacia, Piscataway, NJ) spun column. The probes were hybridized to the blot following standard procedures.

GenBank Accession Numbers. The sequences reported here have the GenBank accession numbers AF004227, AF004228, and AF004229.

\section{Results}

Randomly Amplified Polymorphic DNA Primer Screening. Of 300 primers screened, 3 amplified polymorphic DNA fragments useful for diagnostic purposes. Primer OPG-03 amplified a fragment 928 base pairs (bp) long (FS-2) in North American but not Asian gypsy moths (Fig. 1a). Primer OPH-11 amplified a 612-bp fragment (FS-3) also seen in North American but not Asian moths (Fig. 1b). Primer OPP-03 amplified a 699-bp fragment (FS-4) in Asian but not North American gypsy moths (Fig. 1c). All 3 primers amplified additional fragments in some or all moth samples that were not diagnostic for either population.

Cloning and Characterization of Amplified Fragments. The FS-2, FS-3, and FS-4 marker DNA fragments were cloned into the pCRII vector for further characterization. To verify that the correct fragments had been cloned and that comigrating RAPD-PCR fragments were homologous, for each marker the amplified DNA was blotted onto nylon membranes and probed using the appropriate gel purified plasmid insert DNA. The results are shown in Fig. $1 \mathrm{~d}-\mathrm{f}$. In all 3 cases, the marker fragments contained DNA homologous to the cloned plasmid DNA.

The hybridization of the FS-2 probe to the blot of amplified DNA revealed an amplified fragment in an Asian moth (Fig. 1d, lane 1), which was not visible in the ethidium bromide-stained gel (Fig. 1a). The FS- 2 marker was visibly amplified in $\approx 4 \%$ of Asian moths, and apparently other moths within the Asian population have DNA sequences weakly homologous to the FS-2 target genomic region allowing limited amplification.

Analysis of Asian and North American Samples. The 3 RAPD primers, OPG-03, OPH-11, and OPP-03 (FS-2, FS-3, and FS-4, respectively) were used to amplify at least 100 Asian and North American moth samples of known origin to confirm their utility as population markers. The results are shown in Table 2, and summarized in Table 3. The FS-2 and FS-3 primers should amplify the marker bands (928 bp and 612 bp, respectively) in North American samples, and should not amplify these bands in 
$M 1234567891011121314 \ldots$

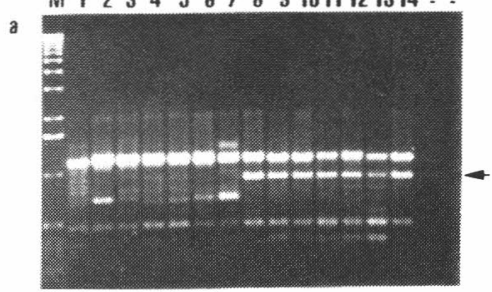

d

M1234567881011121314 .

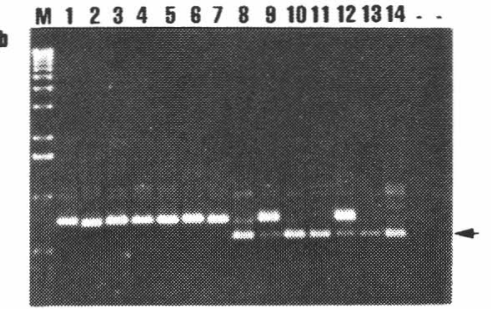

M $1234567891011121314 \ldots$

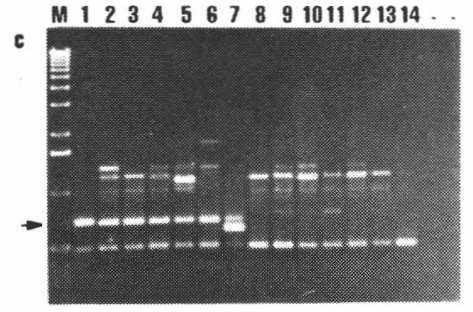

41234567891011121314 f

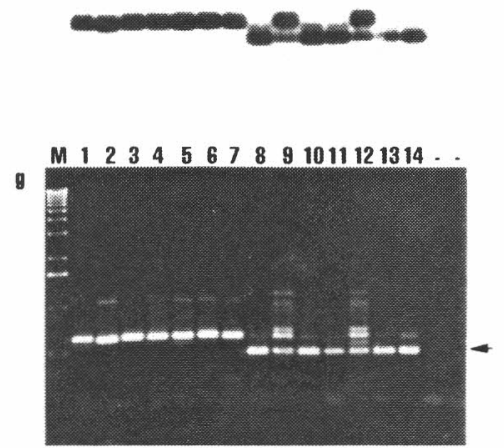

Fig. 1. Amplification products obtained using primers OPG-03 (FS-2), OPH-11 (FS-3), and OPP-03 (FS-4). Lanes labeled $\mathrm{M}$ are 1 kilo base ladder DNA size markers, lanes 1-7 are Asian gypsy moth DNA, and lanes 8-14 are North American gypsy moth DNA samples. Lanes 15 and 16 are DNA-minus PCR controls. (a-c) Ethidium bromide-stained gels of DNA amplified by FS-2, FS-3, and FS-4 primers, respectively. (d-f) Autoradiographs of gels shown in a-c after hybridization with FS-2, FS-3, and FS-4 probes, respectively. (g) Amplification products obtained using FS-3 specific primers H11IF and H11IIR.

Asian samples. The FS-2 marker correctly identified $96 \%$ of Asian samples and $99 \%$ of North American samples. The FS-3 marker correctly identified $88 \%$ of Asian moths and $87 \%$ of North American moths. The FS-4 primer should amplify the 699-bp fragment in Asian samples and should not amplify the fragment in North American samples. When tested on samples from known locations, the FS-4 marker was correct in identifying $97 \%$ of Asian samples and $98 \%$ of North American samples.

Analysis of Hybrid Samples. The 3 RAPD primers, OPG-03, OPH-11, and OPP-03 (FS-2, FS-3, and FS-4) were used to amplify at least $50 \mathrm{~F}_{1}$ hybrids to investigate their utility for identification of hybrid gypsy moths. The 3 marker fragments should be amplifiable in all $F_{1}$ hybrids if the target genomic region is inherited in a Mendelian fashion and if the parents are homozygous for that region. Hybrids used were from crosses between North American individuals collected in Massachusetts, New Jersey, and North Carolina and Asian moths originating from Japan and far eastern Russia. Crosses were performed using North American females bred to Asian males and Asian females bred to North American males. However, only male hybrid offspring were analyzed in this study, so sex chromosome linkage of these markers could not be determined (females are the heterogametic sex in moths). The results of marker amplification are shown in Table 2. The FS-2 marker fragment (specific for North American moths) was amplified in $82 \%$ of hybrid moths, the FS-3 marker (also North American-specific) was amplified in $73 \%$ of hybrids, and the Asian-specific FS- 4 band was amplified in $97 \%$ of the hybrid samples.

In practice, hybrid gypsy moths can be distinguished from parental types only if at least 1 Asianspecific and 1 North American-specific marker can be analyzed upon amplification of each moth sample. Therefore, because the FS-2, FS-3, and FS-4 primers each amplify only 1 marker, the results must be considered in combination. When the results described above were counted for the presence of both an Asian and a North American marker, both the FS- 2 and FS- 4 markers were amplified in $83 \%$ of the known $\mathrm{F}_{1}$ hybrid samples (Table 3). Both the FS-3 and FS-4 markers were amplified in $72 \%$ of the samples. Only $60 \%$ of known hybrids showed the presence of all 3 of the expected marker fragments; however, if the appearance of either the FS-2 or FS-3 fragment was considered to indicate a North American parent, $94 \%$ 
Table 2. Analyses of gypsy moths from known locations with the FS-2, FS-3, and FS-4 markers

\begin{tabular}{|c|c|c|c|c|c|c|}
\hline \multirow{2}{*}{ Origin/Strain } & \multicolumn{2}{|c|}{ FS-2 } & \multicolumn{2}{|c|}{ FS-3 } & \multicolumn{2}{|c|}{ FS-4 } \\
\hline & None & N. Am. & None & N. Am. & None & Asian \\
\hline \multicolumn{7}{|l|}{ Asian } \\
\hline $\mathrm{CH}$ & 19 & 1 & 17 & 3 & 0 & 20 \\
\hline JA & 14 & 0 & 17 & 1 & 1 & 15 \\
\hline $\mathrm{RB}$ & 8 & 2 & 7 & 3 & 0 & 10 \\
\hline $\mathrm{RM}$ & 51 & 2 & 46 & 6 & 0 & 46 \\
\hline Ship & 21 & 0 & 24 & 2 & 3 & 24 \\
\hline Total & 113 & 5 & 111 & 15 & 4 & 115 \\
\hline \multicolumn{7}{|l|}{ Hybrid } \\
\hline $\mathrm{NJ} \times \mathrm{JA}$ & 3 & 21 & 2 & 22 & 1 & 22 \\
\hline $\mathrm{MA} \times \mathrm{RM}$ & 4 & 15 & 7 & 10 & 1 & 9 \\
\hline $\mathrm{NC} \times \mathrm{RM}$ & 6 & 27 & 11 & 23 & 0 & 33 \\
\hline Total & 13 & 63 & 20 & 55 & 2 & 64 \\
\hline \multicolumn{7}{|l|}{ North American } \\
\hline CT & 0 & 10 & 1 & 9 & 9 & 0 \\
\hline MA & 0 & 26 & 3 & 29 & 28 & 3 \\
\hline MI & 0 & 26 & 6 & 21 & 26 & 0 \\
\hline $\mathrm{NC}$ & 0 & 19 & 7 & 18 & 23 & 0 \\
\hline NJSS & 0 & 9 & 0 & 14 & 11 & 0 \\
\hline $\mathrm{OH}$ & 0 & 4 & 1 & 4 & 3 & 0 \\
\hline PA & 1 & 11 & 1 & 11 & 12 & 0 \\
\hline WV & 0 & 22 & 1 & 23 & 21 & 0 \\
\hline Total & 1 & 127 & 20 & 129 & 133 & 3 \\
\hline
\end{tabular}

Numbers in columns indicate moth samples showing presence of North American (N. Am.) or Asian markers, or absence of markers (none). Sample origins (numbers analyzed): CH, China: Beijing (5), Hubei (5), Liaoning (5), and Shandong (5). JA, Japan; Hokkaido (10), Ibaraki, Honshu (8). RB, Bellyk, central Russia. RM, Mineralni, far-eastern Russia. Ship, ships intercepted on route from far-eastern Russia. North American samples are indicate by state or origin except that NJSS refers to New Jersey Standard Strain, a laboratory strain.

of the known hybrids could be typed as such when the FS-4 Asian marker was also counted.

The FS-3 marker had a higher level of heterogeneity than the other 2 markers within the parental populations, with $11-12 \%$ of the parental populations failing to type as expected (Table 2). In addition to the marker fragment, the FS-3 primers often amplified an additional fragment approximately 120 bp longer (see Fig. 1 b, e, and g, lanes $1-7,9$, and 12). This fragment contained DNA related to the marker band as indicated by hybridiza-

Table 3. The proportion of samples correctly identified using moth samples of known origin

\begin{tabular}{|c|c|c|}
\hline & Asian Samples & $\begin{array}{c}\text { North American/ } \\
\text { Hybrid Samples }\end{array}$ \\
\hline FS-2 & $\begin{array}{l}\text { Asians: } 95.8 \% \\
113 / 118\end{array}$ & $\begin{array}{l}\text { North American: } 99.2 \% \\
127 / 128\end{array}$ \\
\hline FS-3 & $\begin{array}{l}\text { Asians: } 88.0 \% \\
111 / 126\end{array}$ & $\begin{array}{l}\text { North American: } 86.6 \% \\
129 / 149\end{array}$ \\
\hline FS-4 & $\begin{array}{l}\text { Asians: } 96.6 \% \\
115 / 119\end{array}$ & $\begin{array}{l}\text { North American: } 97.8 \% \\
133 / 136\end{array}$ \\
\hline FS-2 + FS-4 & & $\begin{array}{l}\text { Hybrids: } 83.1 \% \\
54 / 65\end{array}$ \\
\hline FS-3 + FS-4 & & $\begin{array}{l}\text { Hybrids: } 71.9 \% \\
46 / 64\end{array}$ \\
\hline FS-2 + FS-3 + FS-4 & & $\begin{array}{l}\text { Hybrids: } 60.3 \% \\
38 / 63\end{array}$ \\
\hline FS- 2 or FS-3 + FS- 4 & & $\begin{array}{l}\text { Hybrids: } 93.8 \% \\
60 / 64\end{array}$ \\
\hline
\end{tabular}

tion of cloned marker DNA to a blot of DNA amplified by the FS-3 primers (Fig. 1e). It is possible that the 2 fragments amplified by the FS- 3 primers represent 2 forms of a size polymorphism. When bands of both sizes were counted, 20 of 149 North American samples (13\%) had only the larger band, $19(13 \%)$ had both bands (scored as positive for the North American marker), and the remaining 110 (74\%) had only the marker band. Among Asian moths, 111 of 126 (88\%) had the larger band, 5 (4\%) had both bands, and $10(8 \%)$ had only the North American marker band. Of 75 hybrids tested, 50 had both bands (67\%), 20 (27\%) had only the larger band and $5(7 \%)$ had only the smaller band. If the 2 FS-3 fragments are allelic, then $13 \%$ of the North American samples tested are heterozygous for the smaller fragment identified as the North American marker. If this is the case, it would not be possible for the FS-3 marker to detect all $F_{1}$ hybrid moths.

Sequence Analysis of Marker Fragments. The nucleotide sequences of the FS-2, FS-3, and FS-4 are shown in Fig. 2 a-c respectively. The location of locus-specific primer sequences for the FS-3 marker are shown in Fig. 3b. The 3 marker sequences were highly AT-rich, particularly those of FS-2 and FS-4. The FS- 2 sequence was $67 \% \mathrm{~A}+\mathrm{T}$; the FS-3 sequence was $59 \% \mathrm{~A}+\mathrm{T}$; and the FS-4 sequence was $72 \% \mathrm{~A}+\mathrm{T}$. Repeated sequences were found in all 3 marker regions. The FS-2 sequence contained 2 copies of an imperfect repeat $\approx 106 \mathrm{bp}$ in length at positions 21-126 and 319-425, as well as 5 copies of a $4 \mathrm{bp}$ ACAG repeat from position 455-474. The FS-3 sequence contained 4 imperfect copies of a 17-bp repeat extending from nucleotide 313 to 381 , and the FS-4 sequence contained 4 imperfect copies of an 11-bp repeat from nucleotide 289 to 332 . The marker sequences contained no long open reading frames, and searches of the GenBank databases with the DNA sequences have not yielded significant matches.

Genomic Southern Blots. The FS-2, FS-3, and FS-4 plasmid insert fragments were radioactively labeled and hybridized to blotted genomic gypsy moth DNA digested with BamHI. The results are shown in Fig. 3. All 3 probes hybridized as smears, indicating that the marker fragments contained repetitive DNA sequences that are dispersed within the gypsy moth genome.

Specific Primer Selection and Testing. Several sets of primers designed to amplify portions of the sequence regions containing the FS-2, FS-3, and FS-4 marker polymorphisms were selected. All primers used in these studies are listed in Table 1. Seven upper and 6 lower primers were selected for the FS-2 marker. In all combinations, FS-2 specific primers amplified fragments other than the expected size. Fragments appearing to be the expected size were seen, but these were seen in Asian as well as North American moths. Of the FS-3 specific primers, all amplified the expected diagnostic band, with H11IF and H11IIR giving the strongest amplification (Fig. $1 \mathrm{~g}$ ). The FS-4 specific primers 


\section{a. $\mathrm{FS}-2$}

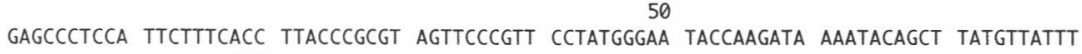
100

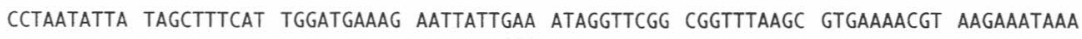
200

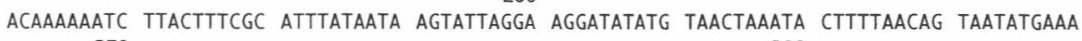
250 300

GTGTCATGTA GCCCCTTTAA ATTTTATTCA TTACTAGCAA CCCGCCCTCG CTTCGCTTCA GTTATAGGTT ATAATCGTTT 350

TACCCGCGTA GTTGCCGTTC CCGTGGGAAT ACTGGGATAA AATATAACCT AGTTTACGCC CTGATATTAT AGCTTTCCAT 450

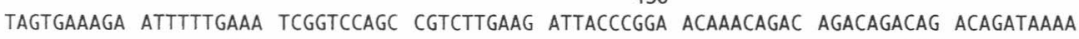

500

AATTTTTAAT TGCTATTTTA GGCATAGGTG TCGTGCAAAT AACCGTGTGA ACCTGAAAAA AGCCTATTAT TTTGACATTA 600

CAAACAGACA CTCCAATTTT ATTTATTGGT ATAGATTGTA GTGTTTTACA GTGTAATATT GTATAATTTT TTTAGTATTT 650 700

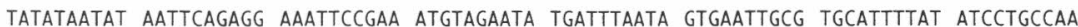
750
AATTGCCAAA GAAATCTGAT TTGGTTGTCA GCATCAATGG TAGCAACTAA GACTAATATG AAGAGGCTAT AGACGTATTA 850 AGGTGAATAT AATGACTTGA CACTTGCACC TGCTATGAGC TACTTATATT ATTGTAGCTT ATTGACAATA AAAAAGAAGA 900

AGATGTATTT AAATATTTAT AGTATCAAAA TTTTCGTGTG GAGGGCTC

b. FS-3

H11IF 50

CTTCCGCAGT GTCTGAATAC AAAGGTTTAT AATCAGTGCG TGTTAGCAGC GATGACATGT GGCACTGAAA CGCGGTCTAA 100

ATTTCGGCTT TATGAAAAGG CTCACAGTCG CCCAACGTGC TATAGAGAGG GTTATGCTCG GTATTTCTCT ACGTGATCAA 200

ATCCGGAATT TTGTTGAaGA ACGAATGTAA CCGACATAGA CCGACGAATT AACAAGTTGA AATGGCAATA GGCAGGCCAC 250 300

ATTGITCATC GAACTAACAA CCTATAGGAA GAAATTTTTT TATATTAAAG CCTACATTTA GAAGACGATG ATAACGAAAA

$350 \quad 400$ GACCATGGTG ACGAAAAGAC CATGATGAAG AAAAGACCAT GATGAAGAAA AGACCATGAT GAAGATACAA GTACATATTG

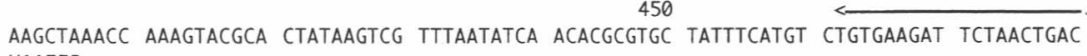
HIIIIR

500
GCGTCATTTC CGTGCCTAGT GTTGGTAGAC TATTCTGACA GTGTCAGTTA CTCTGTGAGG ATATCAAGAG ACCATTGTCG AAATGTAAAA GCACGCCAGC CGCCTTTTGT TCTGTGGTAT GGACTGCGGA AG

c. FS-4

CtGATACGCC ATtATTGCAG TtTGTACATT TACAATTTGC CTAATTCTTT TAATGCGTAG ACAAAACAAT CTATTTTGTG 100

TGTTATTTTT TTGATATGTA GTTTCCAATT ACAAAACCTA TCCATAGTTA TACCCAAGAA TATACAATCG TTAACCGTAT 200

TCAATGTCTC GTTTTTATAA TTAATATTTA GGTTTGTTTT GTCAGCTTTA TGTGTTTTAA AATGTATAAT ATTTGTTTTT 250 300

GTCATGTTTA CATCGCGCGA TAAATTACTA AACTACTAAA ATCAAGCCTT AACTTAAATG TAACTTATAT TAAACTTAAA 350

400 TGTAACTTAT ATATACTATT GATAAATAGC AAAGGCACTT TAAGTAATTA ACATTTAACC ATTACGATAT ACTTTGGACA 450
ITTGTCTGTC TATTGTTTGT GTAAGTGAAC AACTTAAGTA ATGAAATGAT ACGAATGTAT TTTGTTACTA TCTAACCTCT
500 TAAACTAATG ATCTTAGACG AATTAATAGA TGAGAAACTT ATAGGGAATA TATAAATCTA TATACATATA TTTCCGGAGT 600

AAGAATACAA TTCATTACCC TCTTTTTTAC CCTTGGTTGT CGTATAAGAC GACTAAGGGA TATAATATGC ATATAATATC $650 \quad 699$

TATGCAAGAG AAGAAAACTC GTAATAAAAT CCTATATCAA CCCACCAGCG GCGTATCAG

Fig. 2. Sequences of gypsy moth marker DNA fragments. (a) FS-2. (b) FS-3. Locations of specific primers H11IF and H11IIR are shown by arrows. (c) FS-4. 


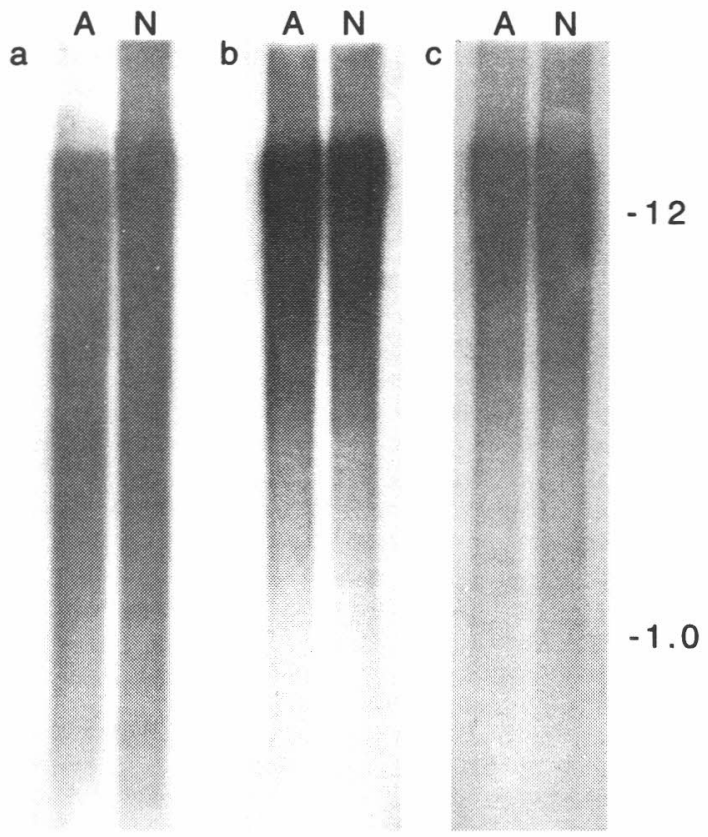

Fig. 3. Autoradiographs of BamHI-digested genomic DNA blots hybridized with cloned marker DNA probes. Lanes A contain Asian gypsy moth DNA and Lanes N contain North American moth DNA. (a) FS-2 probe. (b) FS-3 probe. (c) FS-4 probe.

amplified fragments of the predicted size, but the same fragments were seen in all individuals, whether of Asian or North American origin.

\section{Discussion}

We have identified 3 RAPD-PCR based markers, FS-2, FS-3, and FS-4, which can be used to differentiate Asian and North American strains of the gypsy moth. The 3 markers exhibited accuracy rates of $95.8,88.0$, and $97 \%$, respectively, when tested on known Asian moths and 99.2, 86.6, and $98 \%$ when tested on moths of North American origin. The probability of determining the correct identity of an Asian moth when all 3 markers agree is $99.98 \%$, and for a North American moth the probability is $99.99 \%$. The 3 new markers will improve the accuracy of identification of gypsy moth specimens in regions where introductions of Asian moths are suspected.

The FS-2, FS-3, and FS-4 markers can also identify a significant portion of known $\mathrm{F}_{1}$ hybrids if used in combination (83\% using FS-2 and FS-4, 72\% using FS-3 and FS-4). The FS-4 marker results were sufficiently accurate that the FS- 4 will be useful as an indicator of Asian parentage in unknown populations. However, the inheritance of the FS-2 and FS-3 markers in $F_{1}$ hybrids was not as high as expected. A likely explanation is heterozygosity of the target genomic region in the North American gypsy moth population, particularly in the case of
FS-3. More complex patterns of inheritance could also be occurring. Because all 3 RAPD-amplified marker fragments contained highly repetitive DNA sequences, it is uncertain whether the target genomic regions consist of single or multiple loci. Interactions such as competitive primer binding at 2 or more target sites could be involved in the presence or absence of the marker DNA fragment. It also remains to be determined whether the FS-2, FS-3, and FS-4 markers show sex linkage. However, because the markers were developed for use on DNA from male moths captured in pheromonebaited traps, $\mathrm{Z}$ chromosome linked markers would detect hybrids because the male gypsy moths inherit a $\mathbf{Z}$ chromosome from each parent.

Following DNA sequence analysis of the amplified marker regions, it was possible to develop locus-specific primers 20 nucleotides in length for the FS-3 marker. Frequently, locus-specific primers, which can be used with more stringent reaction conditions, are more sensitive than RAPD-PCR and may produce more reproducible results under varying laboratory conditions (Paran and Michelmore 1993).

Attempts were made to develop locus-specific primers for the FS-2 and FS-4 markers. For the FS-2 marker, 7 different upper and 6 lower primer sequences were tested in all combinations. In most cases, multiple fragments were amplified and often the strongest bands were not of the predicted size. One lower primer amplified several fragments when used alone. The large number of amplified bands as well as results of a genomic Southern blot indicate that part or all of the FS-2 sequence is highly repetitive, which could account for the difficulty in finding useful specific primer sequences.

Locus-specific primers were also designed based on the FS-4 sequence. Three upper and 3 lower primers were tested, but all combinations resulted in amplification of the DNA fragment of the predicted size in both Asian and North American moths. It is possible that the Asian/North American polymorphism is within one or both of the 10nucleotide RAPD primer binding sites resulting in differential amplification. The sequence within the Asian RAPD-amplified region may be nearly identical to that of the corresponding North American sequence, resulting in the failure of the internal primer sequences to distinguish the 2 strains.

Although they exhibit significant developmental and behavioral differences, Asian and North American gypsy moths appear to be poorly differentiated genetically, based on the low proportion of RAPDPCR fragments that differ between the 2 strains. Only 4 useful markers have been found upon testing > 500 RAPD primers (Garner and Slavicek 1996, this work). A small number of false positives or negatives may occur with any single marker used, because of heterogeneity within the Asian and North American populations. However, use of several markers on the same suspect moth sample will result in a higher probability of correct identifica- 
tion. Accuracy of identification of gypsy moths is critical because treatment of Asian moth infestations must cover larger areas because of the increased migration ability of flying Asian females. In addition, Asian moths have a wider host range that includes economically important conifers, so failure to rapidly eliminate an Asian moth infestation may have more costly consequences. The new gypsy moth markers described in this paper should improve the ability to make correct management decisions concerning millions of dollars in treatment costs and potential impacts.

\section{Acknowledgments}

We thank Melody Keena for Asian, European, and North American specimens and for generation of hybrids and backcross samples. We also thank Bonita Baldwin, Alan Baumgard, Hermann Bogenschutz, Lee Humble, Vic Mastro, Mary Smallsreed, and Regis Young for additional samples. We are grateful to Melody Keena and Marie-José Côté for their critical reviews of the manuscript.

\section{References Cited}

Bogdanowicz, S. M., W. E. Wallner, J. Bell, T. M. ODell, and R. G. Harrison. 1993. Asian gypsy moths (Lepidoptera: Lymantriidae) in North America: evidence from molecular data. Ann. Entomol. Soc. Am. 86: 710715 .

Dowdy, A. K., and W. H. McGaughey. 1996. Using random amplified polymorphic DNA to differentiate strains of the Indianmeal moth (Lepidoptera: Pyralidae) Environ. Entomol. 25: 396-400.

Favia, G., G. Dimopolous, and C. Louis. 1994. Analysis of the Anopheles gambiae genome using RAPD markers. Insect Mol. Biol. 3: 149-157.

Forbush, E. H., and C. H. Fernald. 1896. The gypsy moth. Boston, Wright and Potter, State Printers, Boston, MA

Garner, K. J., and J. M. Slavicek. 1996. Identification and characterization of a RAPD-PCR marker for distinguishing Asian and North American gypsy moths. Insect Mol. Biol. 5: 81-91.

Gawel, N. J., and A. C. Bartlett. 1993. Characterization of differences between whiteflies using RAPD-PCR. Insect Mol. Biol. 2: 33-38.

Gibbons, A. 1992 Asian gypsy moth jumps ship to United States. Science (Wash. D.C.) 255: 526.

Graser, V. E., A. Wulf, and W. Burgermeister. 1995. Intraspecific variation of gypsy moth (Lymantria dispar) revealed by RAPD-PCR. Nachrbl. Dtsch. Pflanzenschutzd. 47: 25-27.

Ish-Horowicz, D., S. M. Pinchin, P. Schedl, S. ArtavanisTsakoncis, and M. Mirault. 1979. Genetic and mo- lecular analysis of the $87 \mathrm{~A} 7$ and $87 \mathrm{C} 1$ heat-inducible loci of Drosophila melanogaster. Cell 18: 1351-1358.

Keena, M. A. 1994a. Genetics and biology of Asian gypsy moth and its hybrids. Proceedings, U.S. Department of Agriculture Interagency Gypsy Moth Research Forum. U.S. Dep. Agric. Gen. Tech. Rep. NE188.

1994b. Identification of gypsy moth larval color forms. U.S. Dep. of Agric. For. Serv. Leaf. NE/NA-INF-12394.

Keena, M. A., P. S. Grinberg, and W. E. Wallner. 1995. Asian gypsy moth genetics: biological consequences of hybridization. In Proceedings, U.S. Department of Agriculture Interagency Gypsy Moth Research Forum. U.S. Dep. Agric. Gen. Tech. Rep. NE-213.

Montgomery, M. E., and Y. N. Baranchikov. 1995. Comparison of performance on several tree species of gypsy moth from central Asia, North America, and their hybrids. Proceedings, U.S. Department of Agriculture Interagency Gypsy Moth Research Forum. U.S. Dep. Agric. Gen. Tech. Rep. NE-213, p. 97.

Mudge, A. D., D. J. Hilburn, and K. J.R. Johnson. 1994. Gypsy moth detection and eradication programs in Oregon, pp. 319-324. In Proceedings of the 1994 Annual Gypsy Moth Review. Oregon Department of Agriculture, Salem, OR.

Paran, I. and R. W. Michelmore. 1993. Development of reliable PCR-based markers linked to downy mildew resistance in lettuce. Theor. Appl. Genet. 85: 985993.

Pfeifer, T. A., L. M. Humble, M. Ring, and T. A. Grigliatti. 1995. Characterization of gypsy moth populations and related species using a nuclear DNA marker. Can. Entomol. 127: 49-58.

Rychlik, W. 1992 OLIGO version 4.0 for Macintosh, Pub. By National Biosciences, Plymouth, MN.

South, M. D. 1994 North Carolina update. Gypsy Moth News 34: 12.

Wallner, W. E., P. S. Grinberg, and M. A. Keena. 1994. Female flight: evaluation of Asian gypsy moth and its hybrids. U.S. Department of Agriculture Interagency Gypsy Moth Research Forum. U.S. Dep. Agric. Gen. Tech. Rep. NE-188.

Williams, J.G.K., A. R. Kubelik, K. J. Livak, J. A. Rafalski, and S. V. Tingey. 1991. DNA polymorphisms amplified by arbitrary primers are useful as genetic markers. Nucleic Acids Res. 18: 6531-6535.

Wood, J. 1994 Washington State Department of Agriculture, Plant Services Division. Gypsy moth program summary report, pp. 334-342. In Proceedings of the 1994 Annual Gypsy Moth Review. Oregon Department of Agriculture, Salem, OR.

Received for publication 24 March 1997; accepted 19 May 1997. 